\title{
Pulmonary capillary haemangiomatosis causing pulmonary arterial hypertension: a clinician's conundrum
}

\author{
Arun Sharma, Niraj Nirmal Pandey, Sanjeev Kumar
}

Department of Cardiovascular Radiology \& Endovascular Interventions, All India Institute of Medical Sciences, New Delhi, India

\section{Correspondence to}

Dr Sanjeev Kumar,

sanjeevradio@gmail.com

AS, NNP and SK contributed equally.

Accepted 20 September 2018

Check for updates

(C) BMJ Publishing Group Limited 2018. No commercial re-use. See rights and permissions. Published by BMJ.

\footnotetext{
To cite: Sharma A,

Pandey NN, Kumar S. BMJ

Case Rep Published Online

First: [please include Day

Month Year]. doi:10.1136/

bcr-2018-227393
}

\section{DESCRIPTION}

Pulmonary capillary haemangiomatosis $(\mathrm{PCH})$ is a rare cause of pulmonary hypertension which poses a considerable diagnostic challenge. Here, we describe the case of a 14-year-old boy with gradually progressive exertional dyspnoea and cough for past 4 months. Frontal chest radiograph demonstrated prominent pulmonary artery segment with diffuse nodular opacities in bilateral lung fields (figure 1A). CT angiography was performed to diagnose the aetiology of pulmonary artery hypertension. It revealed dilated central pulmonary arteries (figure 1B) with multiple ill-defined centrilobular nodules diffusely distributed in both lungs (figure 1C,D). No interlobular septal thickening, pulmonary thromboembolism, pleural effusion or any intracardiac/extracardiac shunt was seen. A provisional diagnosis of $\mathrm{PCH}$ was made which was subsequently confirmed on a lung biopsy.

Clinical presentation of $\mathrm{PCH}$ is non-specific and generally confused with primary pulmonary hypertension and pulmonary veno-occlusive disease (PVOD). ${ }^{12}$ Characteristic imaging findings in $\mathrm{PCH}$ include the presence of diffuse, ill-defined, centrilobular nodules or ground-glass opacities with scarce

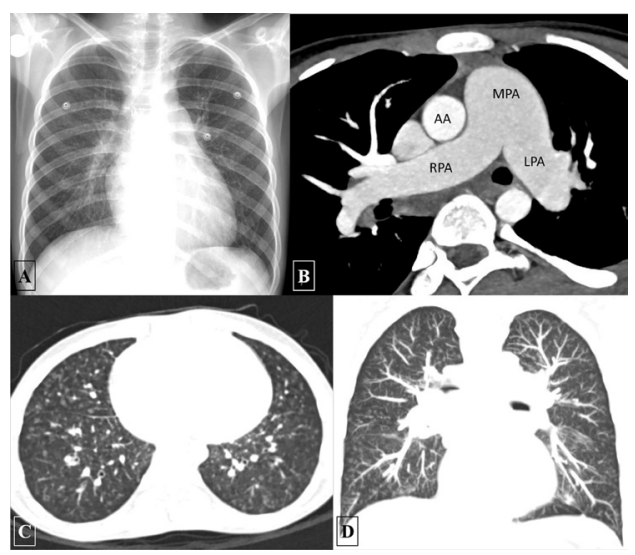

Figure 1 Frontal chest radiograph (A) revealing prominent pulmonary artery segment with reticulonodular opacities predominantly involving the lower zones. No Kerley lines were noted. Axial maximum intensity projection images of $C T$ angiography (B) showing dilated MPA, RPA and LPA. No intraluminal filling defects are seen. Axial (C) and coronal (D) lung window images showing the presence of diffuse, ill-defined, centrilobular nodules in both lungs. No septal thickening or any other parenchymal lesion noted. $A A$, ascending aorta; $L P A$, left pulmonary artery; MPA, main pulmonary artery; RPA, right pulmonary artery. septal lines and the presence of haemorrhagic pleural effusions. In contrast, septal lines are frequently encountered in PVOD while haemorrhagic effusions are extremely uncommon. ${ }^{1}$ Correct diagnosis is imperative as standard vasodilator therapy or prostacyclin infusion, a mainstay in the treatment of pulmonary hypertension, can result in sudden respiratory distress and death (due to florid pulmonary oedema) in these patients. ${ }^{3}$ Treatment with recombinant interferon-alpha-2a has been shown to lead to stabilisation of disease or even improvement in a few reported cases. However, lung transplantation remains the only definitive treatment for $\mathrm{PCH}$.

\section{Learning points}

- Pulmonary capillary haemangiomatosis $(\mathrm{PCH})$ is an uncommon cause of pulmonary hypertension with non-specific clinical presentation, overlapping with primary pulmonary hypertension and pulmonary veno-occlusive disease.

- Characteristic imaging findings include the presence of diffuse, ill-defined, centrilobular nodules or ground-glass opacities with scarce septal lines and the presence of haemorrhagic pleural effusions.

- Precise diagnosis is crucial as a standard treatment of pulmonary hypertension, including vasodilator therapy or prostacyclin infusion, can have catastrophic consequences in these patients.

Contributors AS, NNP and SK: participated sufficiently in the conception of the idea, development of the intellectual content, design, writing and final approval of the manuscript.

Funding The authors have not declared a specific grant for this research from any funding agency in the public, commercial or not-for-profit sectors.

Competing interests None declared.

Patient consent Next of kin consent obtained.

Provenance and peer review Not commissioned; externally peer reviewed.

\section{REFERENCES}

1 Frazier AA, Franks TJ, Mohammed TL, et al. From the archives of the AFIP: pulmonary veno-occlusive disease and pulmonary capillary hemangiomatosis. Radiographics 2007:27:867-82.

2 Ito K, Ichiki T, Ohi K, et al. Pulmonary capillary hemangiomatosis with severe pulmonary hypertension. Circ J 2003;67:793-5.

3 Gugnani MK, Pierson C, Vanderheide R, et al. Pulmonary edema complicating prostacyclin therapy in pulmonary hypertension associated with scleroderma: a case of pulmonary capillary hemangiomatosis. Arthritis Rheum 2000;43:699-703. 
Copyright 2018 BMJ Publishing Group. All rights reserved. For permission to reuse any of this content visit http://group.bmj.com/group/rights-licensing/permissions.

BMJ Case Report Fellows may re-use this article for personal use and teaching without any further permission.

Become a Fellow of BMJ Case Reports today and you can:

- Submit as many cases as you like

- Enjoy fast sympathetic peer review and rapid publication of accepted articles

Access all the published articles

- Re-use any of the published material for personal use and teaching without further permission

For information on Institutional Fellowships contact consortiasales@bmjgroup.com

Visit casereports.bmj.com for more articles like this and to become a Fellow 